\title{
Disintegration of the former SFR Yugoslavia and changes in the ethno-confessional structure of some cities of Bosnia and Herzegovina
}

\author{
Igor Zekanović, Rajko Gnjato \\ University of Banja Luka \\ 1A, Bulevar vojvode Petra Bojovica, Banja Luka, 78000, Republic of Srpska
}

\begin{abstract}
Disintegration of Yugoslav state union, which was carried out marked by ethnic conflicts and creation of new political and geographical subjectivities, resulted in major changes in ethnical and ethno-confessional structure of most of the urban settlements in Bosnia and Herzegovina and especially those which until 1992 had a heterogeneous structure according to listed features. In this context, the biggest changes were recorded in three urban settlements: Sarajevo, Banja Luka and Mostar. Today, these settlements have a role of poles of development and affirmation of individual ethno-national ethno-confessional interests. Sarajevo - of Bosniaks and Islam, Banja Luka - of Serbs and Orthodoxy and Mostar - of Croats and Catholicism. Changes in ethnical and ethno-confessional structure of population of Bosnia and Herzegovina, in the period from 1992 to 1995, strongly contributed to the territorial organization of Bosnia and Herzegovina into two entities, the Republic of Srpska with Serbian majority and Federation of Bosnia and Herzegovina within which the cantons are formed either with the Croatian or Bosniak majority. This division of Bosnia and Herzegovina, according to ethnical or ethno-confessional principle, is again a source of different, and usually conflicting, geopolitical relations and aspirations between mentioned constituents.
\end{abstract}

Keywords: Bosnia and Herzegovina, disintegration, entities, cantons, ethnos, confessions, Sarajevo, Banja Luka, Mostar

\section{Introduction}

Bosnia and Herzegovina, due to specific geographical position and historical, including the contemporary conditions of development, represents extremely complex ethnodemographic, ethno-religious and territorial system. Through a long history, especially the newer part, ethno-demographic and ethno-religious heterogeneity of $\mathrm{B} \& \mathrm{H}$ was the key factor in geopolitical processes in all spheres of social life and space organization. Especially large changes, in the period 1992-1995, were recorded in ethno-territorial and ethno-religious structure. It is this ethno-cultural differentiation, and on this basis the territorial organization of the state space, in modern conditions, that appears as an important factor of internal geopolitical relations and processes with an uncertain outcome (Zekanovic I., 2017, p. 544).

The disintegration of Yugoslav state union, which took place under the mark of ethnic conflicts around the "historical territory", also led to the division of B\&H, by the ethnic principle, into the Republic of Srpska with Serbian ethnic majority and the Federation 
of $\mathrm{B} \& \mathrm{H}$, within which the cantons with Bosniak (Islamic) and Croatial (Catholic) majority are segregated. District Brčko makes special administrative and territorial unit, which in administrative and territorial terms devides the Republic of Srpska into two parts, so in that sence it should be viewed as a geopolitical factor of particular importance.

Characteristic geopolitical processes within $\mathrm{B} \& \mathrm{H}$, as we have already noted, in particular contributed to ethno-cultural and ethno-religious homogenization of those settlements in B\&H which until 1992 had a complex and relatively balanced ethnoconfessional structure, which is primarily related to Sarajevo, Banja Luka and Mostar. Therefore, these settlements today symbolize centers within which a single national, ethic and religious interests of the constituent peoples of Bosnia and Herzegovina are articulated: Sarajevo of Bosniak, Banja Luka of Serbian and Mostar of Croatian ethnic-national interests.

With the end of the World War II and with the proclamation of the Federal Republic of Yugoslavia, Bosnia and Herzegovina was established as one of six socialist republics. The area of B\&H amounted $51.129 \mathrm{~km}^{2}$ or $19.9 \%$ of the territory of former SFRY. The essential functioanl and general social features of $\mathrm{B} \& \mathrm{H}$ in many ways were a product of its central position within SFRY. Its economic development and cultural physiognomy of space in many ways are the product of belonging to the Pannonian, Mountainous Basin and Adriatic region. In ethnic sence B\&H was "Yugoslavia in miniature". In Bosnia and Herzegovina lived Serbs, Muslims and Croats with the same rights, and neither one of the nations was the holder of the national sovereignty. It was the only republic without "major" nation-building people. Therefore, "it was said that B\&H was not Serbian, nor Muslim, nor Croatian, but also Serbian, Muslim and Croatian" (Zekanovic I., 2011, p. 49).

According to the Population Census from 1991, Bosnia and Herzegovina had a total of 4.377.033 residents: 1.902.965 Muslims (43.5\%), 1.366.104 Serbs (31.2\%) and 760.852 Croats (17.4\%). Complex political-geographical processes in Europe, at the end of $20^{\text {th }}$ century, did not bypass SFR Yugoslavia. The former common state disintegrated in the early nineties of the last century. On its territory were formed a new national politicalterritorial communities.

The disintegration processes in the former SFRY, including Bosnia and Herzegovina as an integral part, were marked by civil and ethnic-religious war, which within $\mathrm{B} \& \mathrm{H}$ lasted for three and a half years. The war ended with the signing of the General Framework Agreement for Peace in Bosnia and Herzegovina, in November 1995. It was created a complex state of Bosnia and Herzegovina, specific in many ways.

\section{Literature review}

Basic data on the number, territorial distribution and ethno-confessional of the population in B\&H are found in publications, published by the Central Bureau of Statistics of the Republic of Croatia, the Agency for Statistics of Bosnia and Herzegovina and the Institute of Statistics of the Republic of Srpska, more precisely by analyzing the books of the Census of Population B\&H 1981, 1991 and 2013 (Population of Bosnia and Herzegovina, national composition by settlements, 1995; CENSUS Ethnicity/Nationality, Religion, Mother Tongue Book 02., 2016; Census of population, households and dwellings 
in Bosnia and Herzegovina, 2013., 2016; Census of population, households and dwellings in Republic of Srpska 2013., 2017). Demographic data on the number and distribution of refugees and displaced persons from B\&H and the former SFRY were obtained from the publication "Comparative analysis on access to rights of refugees and displaced persons" published by the Ministry of Human Rights and Refugees of Bosnia and Herzegovina.

For the study of the historical-geographic retrospective of the geospatial of Bosnia and Herzegovina, as well as the analysis of contemporary ethno-demographic and political-geographical processes, we used relevant scientific literature (Popovic, Lukic, 1999; Zekanovic, 2011) and Proceedings from International Scientific Conference (Third Congress of Serbian Geographers with International Participation, Banja Luka, 2011; Geopolitical processes in modern Euro-Asian space, Banja Luka, 2017), more precisely with papers (Pasalic, 2011; Zekanovic, 2017).

\section{Methods and results}

The work is realized by complex general (analysis and synthesis) and special methods immanent geographic and demographic research and techniques of data processing (statistical, graphical) in accordance with historical, geographical, structural, functional and dialectical methodological approach, then determining the changes in the ethnoconfessional structure of the population, and monitoring of political and geographical processes and problems.

The result of the work have indicated that the disintegration processes have caused a large number of political consequences in a wider geopolitical environment and have had a special impact on the spatial distribution of the population and the ethnic over composition of $\mathrm{B} \& \mathrm{H}$ geospatial. They left a strong influence on the changes in the ethnoconfessional structure, which are most prominent in the examples of some cities: Banja Luka, Mostar and Sarajevo, where they established the ethnic consolidation and homogenization of the population.

\section{The impact of civil and ethnic-religious war on ethno-confessional structure of Bosnia and Herzegovina}

Bosnia and Herzegovina is a complex ethno-territorial system, in which, for centuries, three religious-civilization cycles interweave (Orthodox, Catholic, Islamic). In that area, as a result of inter-ethnic and inter-religious conflicts (1992-1995), mentioned civilization cycles today are mostly tangled. But, animosity on ethno-cultural and ethno-confessional basis are still foundation for internal geopolitical relations in the form of "Balkanization". Practically, today, in the area of Bosnia and Herzegovina and the Western Balkans as a whole, we still speak about the balkanization of the Balkans, a process that relies on "internal" assumptions and external influences. The Bosnian and Herzegovina crisis, 1992-1995, and even after that period, manifested all political-geographical elements of balkanization conditioned by factors of local, regional and global character. Elements of local character are related to the interests of the three constituent people in $\mathrm{B} \& \mathrm{H}$ and attempt to create differentiated "national" political-territorial units. Elements of regional character are related to the political-geographical interests of the states from direct and 
relatively close environment, and elements of global character are related to the interests of the major forces (Zekanovic, 2011).

In pre-defined circumstances, conflicting interests of Serbian, Croatian and Muslim (Bosniak) nations resulted in a model of territorial organization of $\mathrm{B} \& \mathrm{H}$, within which no nation has fully realized vital national objectives. Therefore, today, with a lot of reasons, it raises the question: "Whose is Bosnia and Herzegovina?" The answer to this question is in the model of territorial organization of the state space, based on ethnic territoriality of Serbs, Croats and Bosniaks.

From 6 April 1992, in the territory of Bosnia and Herzegovina there was the interethnic, inter-confessional, and in a certain period of time, the war of civil character. After peace negotiations, completed in the air base Wright Patterson (USA), on 21 November 1995, "it was reached The General Framework Agreement for Peace in Bosnia and Herzegovina, and its signing was conducted on 14 December 1995 in Paris" (Popovic, Lukic, 1999).

War period in B\&H, 1992-1995, resulted in deep disorder in all spheres of social life, particularly in demographic structures and changes in the spatial distribution of certain ethnicities. In this sense it was realized the ethnic homogenization or ethnic (ethnoconfessional) differentiation of Bosnia and Herzegovina space. At the same time it makes a model of territorial organization of space, but also an important factor in achieving geopolitical interests of individual ethnicity.

According to estimates of the Ministry for Human Rights and Refugees of Bosnia and Herzegovina, in conflict (1992-1995) "about 250.000 people lost life, and approximately 17.000 is officially listed as missing" (Comparative analysis on access to rights of refugees and displaced persons, 2005, p. 21). Also, according to estimates by the Research and Documentation Center (RDC) Sarajevo and experts in demography in the International Criminal Tribunal for the former Yugoslavia in Hague Ewa Tabeau - direct demographic losses in B\&H amount from 97.207 to 104.732 persons. Serbian demographer Stevo Pašalić believes that "direct demographic losses in $\mathrm{B} \& \mathrm{H}$ amount to a minimum of about 110.000, of which about $31.5 \%$ are Serbs, $60.5 \%$ are Bosniaks, and $8 \%$ Croats and others" (Pasalic, 2011).

After 1992, about 2.2 million people left their homes in Bosnia and Herzegovina, which represents more than a half of pre-war population. Approximately 1.2 million persons sought refugee protection in over 100 countries worldwide. In the period 19921995 the largest number of refugees was registered in the following countries: Germany (320.000), Serbia and Montenegro (297.000), Croatia (170.000), Austria (86.500), Sweden (58.000), Slovenia (43.000), Switzerland (24.500), Turkey (23.500), Netherlands (22.000), USA (20.000), Canada (20.000), Italy (12.100) and Norway (12.000). In the first four countries there was recorded around $72.8 \%$ of the total number of refugees from the territory of $\mathrm{B} \& \mathrm{H}$. At the same time, about one million people was displaced within Bosnia and Herzegovina, and directions of displacement were directed in accordance with ethnocultural, ethno-religious and social interests of the refugee population, which means that Serb refugees from the territory of the Federation of Bosnia and Herzegovina inhabited mostly developed urban centers in the Republic of Srpska, Bosniak population from the Republic of Srpska inhabited urban centers under the control of Bosniak authorities, and 
Croatian population from settlements under the control of Serbs or Bosniaks inhabited the centers in the Federation of B\&H under the control of Croatian Armed Forces (Zekanovic, 2017). Refugee current (1992-1995) contributed to ethnic homogenization and ethnic "purity" of all the areas in B\&H that have been, and who are still, under the authority of certain ethnicity. In this way, the Federation of B\&H has become the Bosniak majority, the Republic of Srpska has become the Serbian majority and some cantons within FB\&H have become of Croatian majority. The process of ethnic homogenization also followed after the signing of the Framework Agreement for Peace in B\&H, when for example 100.000 citizens of Serbian nationality from the area of Sarajevo left the Federation of B\&H (1996), that part of the city which until 1995 was controlled by the Serbian government and Serbian army. We come to the very simple and logical conclusion that the religious and civilization determinants of civil and ethnic-religious war in Bosnia and Herzegovina had a crucial impact on national, ethnic-religious and territorial consolidation or differentiation of $\mathrm{B} \& \mathrm{H}$. This is confirmed by the analysis of the results of the Population Census in B\&H for 1981, 1991 and 2013, especially of leading administrative-management and development centers (Banja Luka, Mostar and Sarajevo), settlements that today symbolize belonging to certain ethnic groups. However, development of these settlements through a long history, almost until the World War II, especially Mostar and Sarajevo, symbolized the center of culture and spirituality of the Serbian people in $\mathrm{B} \& \mathrm{H}$, but also the centers that have suffered centuries-long assimilation in the form of islamization, unition and catholicism, mass starvation and prosecution especially during the World War I and World War II, including the systematic ethnic cleansing during the war in 1992-1995.

\section{Banja Luka}

According to the results of the Census from the year 1981, Banja Luka had 183.618 residents distributed in 52 (54) settlements. In the settlements Radmanići and Šljivno there were no recorded residents. The ethnic structure within the respective area of Banja Luka was as follows: Serbs 93.389 or $50.86 \%$, Croats 30.442 or $16.58 \%$, Muslims 21.726 or $11.83 \% .31 .347$ or $17.07 \%$ declared as Yugoslavs. There were 6.714 or $3.66 \%$ of others or unknown.

In 40 settlements of the area of Banja Luka, Serbs had an absolute majority, and in two relative majority. Croats had an absolute majority in 11 settlements, while Muslims had a relative majority in 1 settlement (Bastasi).

According to Population Census from 1991 Banja Luka had 195.692 residents, from which: Serbs 106.826 or $54.59 \%$, Croats 29.026 or $14.83 \%$, Muslims 28.558 or $14.59 \%$. There were 23.656 Yugoslavs or $12.09 \%$. There were 7.626 or $3.90 \%$ of others or unknown (table 1).

Serbs were the majority in 39 settlements of the Banja Luka area, Croats were the majority in 12 settlements, and Muslims were the majority in one settlement. Two settlements did not have residents.

According to the results of population census in B\&H from 2013 in Banja Luka there were 185.042 residents, and the ethnic structure was as follows: Serbs 165.750 or $89.57 \%$, Bosniaks (Muslims) 7.681 or $4.15 \%$, Croats 5.104 or $2.76 \%$. There were 6.507 or $3.52 \%$ 
of others or unknown. In 54 (52) settlements in the territory of Banja Luka, the Serb population represented the absolute majority (CENSUS Ethnicity/Nationality, Religion, Mother Tongue, 2016).

In contrast to the results of the Population Census of B\&H for 2013, published by the B\&H Statistics Agency, the results of population census of the Republic of Srpska Institute of Statistics show that in Banja Luka in 2013 lived 180.053 persons, and the ethnic structure was as follows: Serbs 162.057 or $90.00 \%$, Bosniaks 6.816 or $3.79 \%$, Croats 4.887 or $2.71 \%$. There were 6.293 or $3.50 \%$ of others or unknown (Census of population, households and dwellings in Republic of Srpska 2013, 2017) (table 1).

Banja Luka - ethnic structure 1981, 1991 and 2013

\begin{tabular}{|c|c|c|c|c|c|c|c|c|c|c|c|c|}
\hline \multirow{2}{*}{$\begin{array}{l}\text { Year of } \\
\text { census }\end{array}$} & \multicolumn{3}{|c|}{$\begin{array}{l}\text { Settlements } \\
\text { (majority) }\end{array}$} & \multirow[t]{2}{*}{ Total } & \multicolumn{2}{|c|}{ Bosniaks } & \multicolumn{2}{|c|}{ Serbs } & \multicolumn{2}{|c|}{ Croats } & \multicolumn{2}{|c|}{$\begin{array}{l}\text { Yugoslavs } \\
\text { and other }\end{array}$} \\
\hline & B & S & $\mathrm{C}$ & & & $\%$ & & $\%$ & & $\%$ & & $\%$ \\
\hline 1981 & 1 & 40 & 11 & 183.618 & 21.726 & 11.83 & 93.389 & 50.86 & 30.442 & 16.58 & 38.061 & 20.73 \\
\hline 1991 & 1 & 39 & 12 & 195.692 & 28.558 & 14.59 & 106.826 & 54.59 & 29.026 & 14.83 & 31.282 & 15.99 \\
\hline $2013^{*}$ & - & 52 & - & 185.042 & 7.681 & 4.15 & 165.750 & 89.57 & 5.104 & 2.76 & 6.507 & 3.52 \\
\hline $2013 R^{\star * *}$ & - & 52 & - & 180.053 & 6.816 & 3.73 & 162.057 & 90.00 & 4.887 & 2.71 & 6.293 & 3.50 \\
\hline
\end{tabular}

Source: Population of Bosnia and Herzegovina, national composition by settlements, Central Bureau of Statistics of the Republic of Croatia, Zagreb, 1995.

* CENSUS Ethnicity/Nationality, Religion, Mother Tongue Book 02. Agency for Statistic of Bosnia and Herzegovina, Bosnia and Herzegovina, Sarajevo, 2016.

** Census of population, households and dwellings in Republic of Srpska 2013. Republika Srpska Institute of Statistics, Banja Luka, 2017.
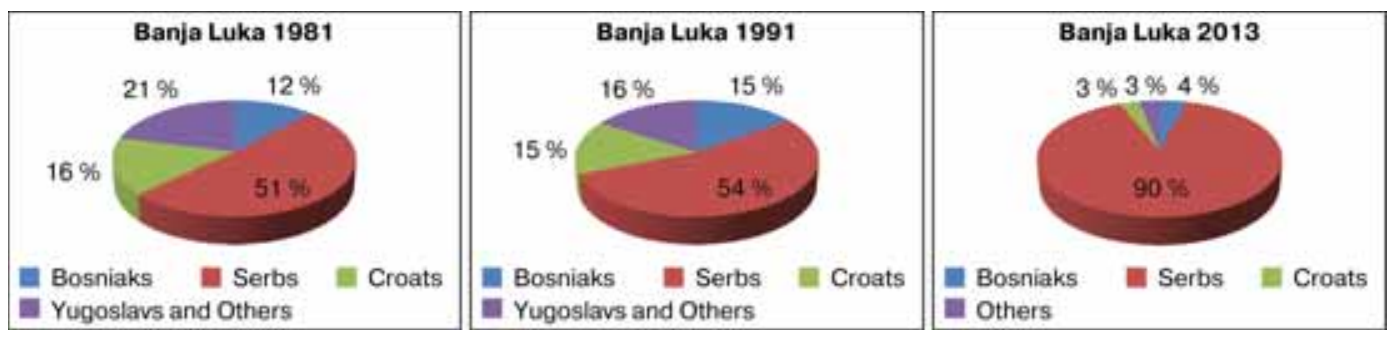

Figure 1. Banja Luka - ethnic structue 1981, 1991 and 2013

\section{Mostar}

City of Mostar, accoding to Population Census from 1981 had 110.337 residents. Croats were the most numerous in the ethnic structure with 36.927 or $33.45 \%$, than Muslims with 34.247 or $31.03 \%$ and Serbs with 20.271 or $18.36 \%$. There were 16.509 Yugoslavs or $14.96 \%$, and 2.423 persons were others (or unknown) or $2.20 \%$.

Out of 57 (1 settlement without residents - Lakševine) recorded settlements that belong to Mostar, Croats represented the majority population in 25 (of which in 19 settlements they had absolute, and in 6 relative majority. Muslims were majority in 19 settlements, of which in 17 settlements absolute and in 2 relative majority. Serbs were majority population in 12 settlements, of which in 10 settlements they had absolute and in 2 relative majority. 
According to Population Census from 1991, Mostar had 126.628 residents. The ethnic structure was as follows: Muslims 43.856 or $34.63 \%$, Croats 43.037 or $33.99 \%$, Serbs 23.846 or $18.83 \%$, Yugoslavs 12.768 or $10.08 \%$, others 3.121 or $2.47 \%$.

Out of 57 settlements, which are included in the urban area of Mostar, Croats were majority in 25 settlements, of which in 19 settlements they had absolute and in 2 relative majority. Muslims were majority in 19 settlements, of which in 15 settlements they had absolute and in 4 relative majority. Serbs were majority in 13 settlements, of which in 9 settlements they had absolute and in 4 relative majority.

According to the results of Population Census from 2013, in 57 settlements which belong to the City of Mostar, without three added settlements, there lived a total of 106.011 residents, of which Croats 51.227 or $48.32 \%$, Bosniaks (Muslims) 46.787 or $44.13 \%$, Serbs 4.587 or $4.33 \%$. There were 3.410 or $3.22 \%$ of othes or unknown (table 2).

Out of 57 settlements, Bosniak (Muslim) population had absolute majority in 28 settlements, Croats had majority in 26 settlements (in 24 absolute and in 2 relative). Serbs were the majority population in three settlements, of which they only had an absolute majority in one settlement and in two relative majority.

Table 2

Mostar - ethnic structure 1981, 1991 and 2013

\begin{tabular}{|l|c|c|c|c|c|c|c|c|c|c|c|c|}
\hline \multirow{2}{*}{$\begin{array}{c}\text { Year of } \\
\text { census }\end{array}$} & \multicolumn{2}{|c|}{$\begin{array}{c}\text { Settlements } \\
\text { (majority) }\end{array}$} & Total & \multicolumn{2}{|c|}{ Bosniaks } & \multicolumn{2}{c|}{ Serbs } & \multicolumn{2}{c|}{ Croats } & \multicolumn{2}{c|}{$\begin{array}{c}\text { Yugoslavs } \\
\text { and other }\end{array}$} \\
\cline { 2 - 14 } & B & S & C & & & $\%$ & & $\%$ & & $\%$ & & $\%$ \\
\hline 1981 & 19 & 12 & 25 & 110.337 & 34.247 & 31.03 & 20.271 & 18.36 & 36.927 & 33.45 & 18.932 & 17.16 \\
\hline 1991 & 19 & 13 & 25 & 126.628 & 43.856 & 34.63 & 23.846 & 18.83 & 43.037 & 33.99 & 15.889 & 12.55 \\
\hline 2013 & 28 & 3 & 26 & 106.011 & 46.787 & 44.13 & 4.587 & 4.33 & 51.227 & 48.32 & 3.410 & 3.22 \\
\hline
\end{tabular}

Source: Population of Bosnia and Herzegovina, national composition by settlements, Central Bureau of Statistics of the Republic of Croatia, Zagreb, 1995, CENSUS Ethnicity/Nationality, Religion, Mother Tongue Book 02, Agency for Statistic of Bosnia and Herzegovina, Bosnia and Herzegovina, Sarajevo, 2016.
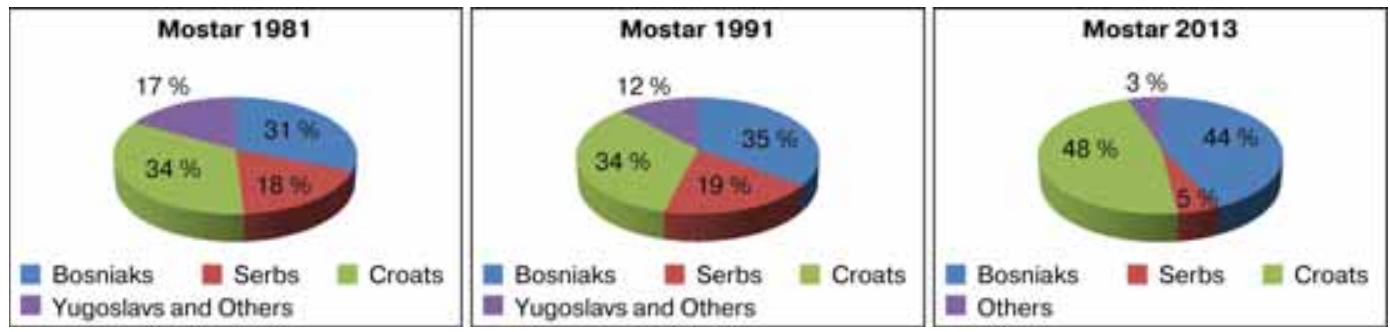

Figure 2. Mostar — ethnic structure 1981, 1991 and 2013

\section{Sarajevo}

According to census from 1981 in City of Sarajevo there were recorded 448.519 persons. In the ethnic structure Muslims were the most numerous with 189.139 persons or $42.17 \%$, than Serbs with 132.646 or $29.82 \%$. Yugoslavs were the third with 71.523 or $15.95 \%$, the fourth were Croats with 36.714 or $8.19 \%$. Unstated population participated with $4.12 \%$ or 18.497 persons.

In administrative terms, City of Sarajevo was divided into 10 municipalities, of which in 6 municipalities Muslims were the majority ethnic group (ethno-confession), in three municipalities they had absolute and in three relative majority. Serbs were the majority 
ethno-confession in 4 municipalities of Sarajevo, and in one they had an absolute majority - Pale.

According to the Population Census the City of Sarajevo had 527.049 residents. The ethnic structure was as follows: Muslims 259.470 or $49.23 \%$, Serbs 157.143 or $29.82 \%$, Yugoslavs 56.470 or $10.71 \%$, Croats 34.873 or $6.62 \%$ and others 19.093 or $3.62 \%$. From a total of 10 municipalities that existed within the city of Sarajevo, Muslims had majority in 8 , of which they had the absolute majority in 6 municipalities. Serbs were the majority population in two municipalities of Sarajevo, of which with absolute majority in one - Pale (table 3).

After 1995, the City of Sarajevo is, in administrative and territorial terms, divided between the Federation of Bosnia and Herzegovina and the Republic of Srpska. The administrative line divides 43 settlements. The Sarajevo Canton was formed out of pats of municipalities Stari Grad, Centar, Novo Sarajevo, Novi Grad, Ilijaš, Hadžići, Ilidža, Trnovo and Vogošća and it belongs to the Federation of Bosnia and Herzegovina (table 5). City of East Sarajevo, which belongs to the Republic of Srpska, is formed out of parts of municipalities: Stari Grad, Novo Sarajevo, Ilidža, Trnovo and municipality of Sokolac (table 6).

Conditional sum of the total number of residents of Sarajevo Canton and residents of the City of East Sarajevo gives the number of 463.992 residents (2013). The ethnic structure for the year 2013 was as follows: Bosniaks (Muslims) 349.192 or $75.26 \%$, Serbs 60.036 or $12.94 \%$, others or unstated 36.830 or $7.94 \%$ (in this category the most people declared as Bosnians 12.897 or $2.78 \%$ of the total population of Sarajevo Canton); Croats 17.934 or $3.86 \%$ (table 4$)$.

Table 3

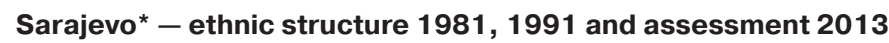

\begin{tabular}{|c|c|c|c|c|c|c|c|c|c|c|c|c|c|c|}
\hline \multirow{2}{*}{$\begin{array}{l}\text { Year of } \\
\text { census }\end{array}$} & \multicolumn{3}{|c|}{$\begin{array}{c}\text { Settlements } \\
\text { (majority) }\end{array}$} & \multirow[t]{2}{*}{ Total } & \multicolumn{2}{|c|}{ Bosniaks } & \multicolumn{2}{|c|}{ Serbs } & \multicolumn{2}{|c|}{ Croats } & \multicolumn{2}{|c|}{ Yugoslavs } & \multicolumn{2}{|c|}{ Others } \\
\hline & $\mathrm{B}$ & $S$ & $\mathrm{C}$ & & & $\%$ & & $\%$ & & $\%$ & & $\%$ & & $\%$ \\
\hline 1981 & 6 & 4 & - & 448.519 & 189.139 & 42.17 & 132.646 & 29.57 & 36.714 & 8.19 & 71.523 & 15.95 & 18.497 & 4.12 \\
\hline 1991 & 8 & 2 & - & 527.049 & 259.47 & 49.23 & 157.143 & 29.82 & 34.873 & 6.62 & 56.470 & 10.71 & 19.093 & 3.62 \\
\hline 2013 & 10 & 5 & - & 463.992 & 349.192 & 75.26 & 60.036 & 12.94 & 17.934 & 3.86 & - & - & 36.830 & 7.94 \\
\hline
\end{tabular}

Source: Population of Bosnia and Herzegovina, national composition by settlements, Central Bureau of Statistics of the Republic of Croatia, Zagreb, 1995, CENSUS Ethnicity/Nationality, Religion, Mother Tongue Book 02, Agency for Statistic of Bosnia and Herzegovina, Bosnia and Herzegovina, Sarajevo, 2016.

* Conditional sum of the residents of Sarajevo Canton (FB\&H) and the City of East Sarajevo (RS)
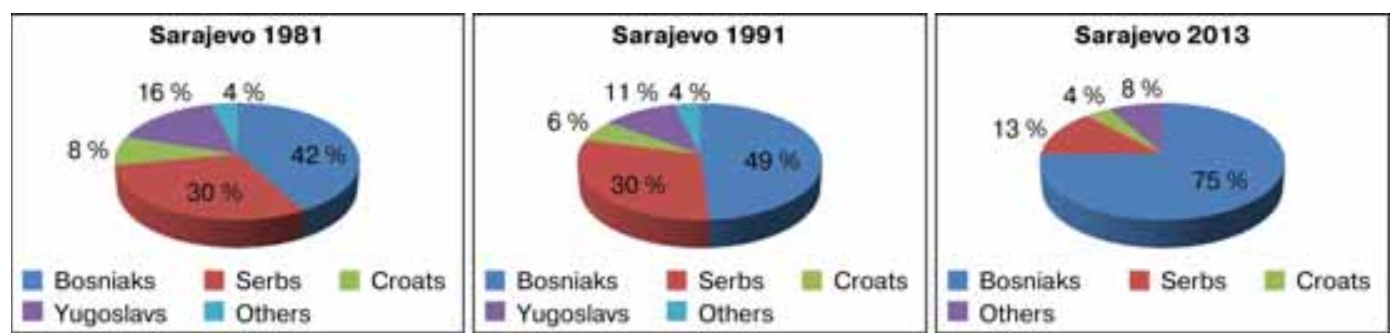

Figure 3. Sarajevo* - ethnic structure 1981, 1991 and assessment 2013

* Conditional sum of the residents of Sarajevo Canton (FB\&H) and the City of East Sarajevo (RS), 2013 
Sarajevo* - ethnic structure according to the assessment from Census 2013

\begin{tabular}{|l|c|c|c|c|c|}
\hline \multicolumn{1}{|c|}{ City/municipality } & Total & Bosniaks & Serbs & Croats & Others \\
\hline Hadžići & 23.891 & 22.120 & 218 & 179 & 1.374 \\
\hline Centa & 55.181 & 41.702 & 2.186 & 3.333 & 7.960 \\
\hline Ilidža & 66.730 & 58.120 & 1.600 & 3.030 & 3.980 \\
\hline Istočna Ilidža & 14.763 & 648 & 13.755 & 156 & 204 \\
\hline Ilijaš & 19.603 & 18.151 & 421 & 382 & 649 \\
\hline Novi Grad & 118.553 & 99.773 & 4.367 & 4.947 & 9.466 \\
\hline Novo Sarajevo & 64.814 & 48.188 & 3.402 & 4.639 & 8.585 \\
\hline Istočno N. Sarajevo & 10.642 & 44 & 10.248 & 107 & 243 \\
\hline Pale & 20.909 & 186 & 20.451 & 128 & 144 \\
\hline Pale FB\&H & 904 & 859 & 33 & 1 & 11 \\
\hline Stari Grad & 36.976 & 32.794 & 467 & 685 & 3.030 \\
\hline Istočni Stari Grad & 1.131 & 43 & 1.071 & 7 & 10 \\
\hline Trnovo RS & 2.050 & 837 & 1.178 & 15 & 20 \\
\hline Trnovo FB\&H & 1.502 & 1.376 & 97 & 4 & 25 \\
\hline Vogošća & 26.343 & 24.351 & 542 & 321 & 1.129 \\
\hline Total & 463.992 & 349.192 & 60.036 & 17.934 & 36.830 \\
\hline
\end{tabular}

Source: CENSUS Ethnicity/Nationality, Religion, Mother Tongue Book 02, Agency for Statistic of Bosnia and Herzegovina, Bosnia and Herzegovina, Sarajevo, 2016.

* Conditional sum of the residents of Sarajevo Canton (FB\&H) and the City of East Sarajevo (RS), 2013.

Table 5

Sarajevo Canton (FB\&H) - ethnic composition in 2013

\begin{tabular}{|l|c|c|c|c|}
\hline \multicolumn{1}{|c|}{ Municipality } & Total & Bosniaks & Serbs & Croats \\
\hline Sarajevo Centar & 55.181 & 41.702 & 2.186 & 3.333 \\
\hline Hadžići & 23.891 & 22.120 & 218 & 179 \\
\hline Ilidža & 66.730 & 58.120 & 1.600 & 3.030 \\
\hline Ilijaš & 19.603 & 18.151 & 421 & 382 \\
\hline Novi Grad & 118.553 & 99.773 & 4.367 & 4.947 \\
\hline Novo Sarajevo & 64.814 & 48.188 & 3.402 & 4.639 \\
\hline Stari Grad & 36.976 & 32.794 & 467 & 685 \\
\hline Trnovo-Fed. & 1.502 & 1.376 & 97 & 4 \\
\hline Vogošća & 26.343 & 24.351 & 542 & 321 \\
\hline Sarajevo Canton & 413.593 & 346.575 & 13.333 & 17.520 \\
\hline
\end{tabular}

Source: Census of population, households and dwellings in Bosnia and Herzegovina, 2013, Agency for Statistics of Bosnia and Herzegovina, Sarajevo, 2016.

City of East Sarajevo (RS) - ethnic composition in 2013

\begin{tabular}{|l|c|c|c|c|}
\hline \multicolumn{1}{|c|}{ Municipality } & Total & Bosniaks & Serbs & Croats \\
\hline Ist. N Sarajevo & 10.401 & 44 & 10.028 & 102 \\
\hline Ist. Ilidža & 14.437 & 632 & 13.455 & 148 \\
\hline Ist. S. Grad & 1.116 & 41 & 1.059 & 6 \\
\hline Sokolac & 11.620 & 629 & 10.894 & 28 \\
\hline Pale & 20.359 & 165 & 19.932 & 126 \\
\hline Trnovo & 1.983 & 818 & 1.131 & 15 \\
\hline Total & 59.916 & 2.329 & 56.499 & 425 \\
\hline
\end{tabular}

Source: Census of population, households and dwellings in Republic of Srpska 2013., Republika Srpska Institute of Statistics, Banja Luka, 2017. 


\section{Conclusion}

War conflicts in Bosnia and Herzegovina (1992-1995) resulted in its division into administrative-territorial systems of individualized ethnic or ethno-confessional characteristics. The division of $\mathrm{B} \& \mathrm{H}$ on ethno-confessional basis largely resulted from the real ethnic differentiation of the area of Bosnia and Herzegovina, to which significantly contributed the war objectives of the warring parties in $\mathrm{B} \& \mathrm{H}-$ Serbs, Croats, Muslims (Bosniaks), including the geopolitical interests of the regional environment and even geopolitical interests of the leading countries of globalism. Thanks to the wider geopolitical interests of some parts of $\mathrm{B} \& \mathrm{H}$, especially its western part, populated with over $90 \%$ of Serbian population, were violently break away from the Republic of Srpska and merged with the Federation of Bosnia and Herzegovina.

The real geopolitical interests of the Serbian and Croatian people in B\&H entailed its division on ethnic, i.e. ethno-confessional basis. Unlike Serbian and Croatian national interests, interests of Muslim or Bosniak people involved a unitary state, i.e. "civil” B\&H, which would, considering the majority and a growing share of Bosniak population, very quickly became an Islamic state.

Changes in the spatial distribution of certain ethnos in B\&H, in the period of 19921995, especially changes in the ethnic composition of the larger cities in B\&H (Banja Luka, Mostar i Sarajevo), confirmed the powerful process of ethnic hegemonization and ethno-religious character of war. On the other hand, conflicts on ethnic and ethnoconfessional basis proved to be a good matrix for breaking up of sovereign states by the protagonists of "democracy" and the global organization of the world. Ethnic purity of previously mentioned urban, administrative and development centers defines the continuity of long-term policy, within which the political Sarajevo will work on the concept of a unitary "civil" B\&H, Banja Luka on the concept of as independent as possible Republic of Srpska and Mostar on the project - model that would provide "third entity" or "independence" and the equality of Croats in B\&H.

(C) Zekanović I., Gnjato R., 2018

This work is licensed under a Creative Commons Attribution 4.0 International License

\section{References}

CENSUS Ethnicity/Nationality, Religion, Mother Tongue Book 02. (2016). Agency for Statistic of Bosnia and Herzegovina, Sarajevo.

Census of population, households and dwellings in Bosnia and Herzegovina, 2013. (2016). Agency for Statistics of Bosnia and Herzegovina, Sarajevo.

Census of population, households and dwellings in Republic of Srpska 2013. (2017). Republika Srpska Institute of Statistics, Banja Luka.

Comparative analysis on access to rights of refugees and displaced persons. (2005). Ministry for Human Right and Refugees, Sarajevo.

Pasalic S. (2011). Demographic losses in B\&H (1991-2011). Proceedings of Third Congress of Serbian geographers with international participation. Banja Luka: Geographical Society of Republic of Srpska, Faculty of Science, University of Banja Luka. Pp. 335-346. 
Popovic V., Lukic V. (1999). Dayton - Paris documents. Banja Luka: Institute for International Law and International Business Cooperation.

Population of Bosnia and Herzegovina, national composition by settlements. (1995). Central Bureau of Statistics of the Republic of Croatia, Zagreb.

Zekanovic I. (2017). Changes in demographic and ethno-territorial distribution of B\&H polulation as consequence of a violent breakup of former SFRY. Proceedings of Geopolitical processes in contemporary Euro-Asian space. Geographical Society of Republic of Srpska, Faculty of Science, University of Banja Luka. Pp. 543-560.

Zekanovic I. (2011). Ethno-demographic basis of the political-geographic position of the Republic of Srpska. Banja Luka: Geographical Society of Republic of Srpska.

Article history:

Received: 30 May 2018

Revised: 17 June 2018

Accepted: 31 October 2018

\title{
For citation:
}

Zekanovic I., Gnjato R. (2018). Disintegration of the former SFR Yugoslavia and changes in the ethno-confessional structure of some cities of Bosnia and Herzegovina. RUDN Journal of Economics, 26(4), 685-696. DOI: 10.22363/2313-2329-2018-26-4-685-696

\section{Bio Note:}

Igor Zekanović, PhD in Geography, Associate Professor, Departman of Geography, Faculty of Sciences, University of Banja Luka, Bosnia and Herzegovina, Republic of Srpska. Contact information: e-mail: igor.zekanovic@pmf.unibl.org

Rajko Gnjato, Doctor of Geography, Full professor, President of the Geographical Society of the Republic of Srpska, Departman of Geography, Faculty of Sciences, University of Banja Luka, Bosnia and Herzegovina, Republic of Srpska.Contact information: e-mail: gnjator@pmfbl.org

\section{Распад бывшей СФР Югославия и изменения в этноконфессиональной структуре некоторых городов Боснии и Герцеговины}

\author{
И. Зеканович, Р. Гньято \\ Университет Баня-Луки \\ Республика Сербская, 78000, Баня-Лука, бульвар герцога Петра Бойовицы, $1 \mathrm{~A}$
}

\begin{abstract}
Распад Югославского государственного союза, который сопровождался этническими конфликтами и созданием новых политических и географических субъектов, привел к серьезным изменениям в этнической и этноконфессиональной структурах большинства городских поселений в Боснии и Герцеговине, особенно тех, которые до 1992 г. имели гетерогенную структуру в соответствии с перечисленными особенностями. В этом смысле самые большие изменения были зафиксированы в трех городских поселениях: Сараево, Баня-Лука и Мостар. Сегодня эти поселения играют роль центров развития и утверждения индивидуальных этнонациональных и этноконфессиональных интересов: Сараево - боснийцев и ислама,
\end{abstract}


Баня-Лука - сербов и православия, Мостар - хорватов и католицизма. Изменения в этнической и этноконфессиональной структурах населения Боснии и Герцеговины в период с 1992 по 1995 г. в значительной степени способствовали территориальной организации Боснии и Герцеговины в два образования: Республику Сербскую с сербским большинством и Федерацию Боснии и Герцеговины, в которых кантоны формируются либо с хорватским, либо с боснийским большинством. Это разделение Боснии и Герцеговины в соответствии с этническим или этноконфессиональным принципом сохраняется и является источником противоречий в геополитических отношениях и устремлениях между указанными участниками.

Ключевые слова: Босния и Герцеговина, распад, образования, кантоны, этносы, признания, Сараево, Баня-Лука, Мостар

\section{История статьи:}

Дата поступления в редакцию: 30 мая 2018

Дата проверки: 17 июля 2018

Дата принятия к печати: 31 октября 2018

\section{Для цитирования:}

Зеканович И., Гньято Р. Disintegration of the former SFR Yugoslavia and changes in the ethnoconfessional structure of some cities of Bosnia and Herzegovina (Распад бывшей СФР Югославия и изменения в этноконфессиональной структуре некоторых городов Боснии и Герцеговины) // Вестник Российского университета дружбы народов. Серия: Экономика. 2018. T. 26. № 4. C. 685-696. DOI: 10.22363/2313-2329-2018-26-4-685-696

\section{Сведения об авторах:}

Зеканович Игор, кандидат географических наук, доцент, декан географического факультета Университета Баня-Луки (Республика Сербская, Босния и Герцеговина). Контактная информация: e-mail: igor.zekanovic@pmf.unibl.org

Гнято Раджако, доктор географических наук, профессор, президент Географического общества Республики Сербской, декан географического факультета Университет БаняЛуки (Республика Сербская, Босния и Герцеговина). Контактная информация: e-mail: gnjator@pmfbl.org 